\title{
Anatomical profile and genetic variability of sweet potato (Ipomoea batatas) cultivars in Banyumas, Central Java, based on RAPD markers
}

\author{
SITI SAMIYARSIH", NUR FITRIANTO, ENUR AZIZAH, WIWIK HERAWATI, ROCHMATINO \\ Faculty of Biology, Universitas Jenderal Soedirman. J1. Dr. Suparno No. 63, Purwokerto Utara, Banyumas 53122, Central Java, Indonesia \\ Tel.: +62-281-638794, Fax. +62-281-631700, `email: asih.fbio@gmail.com, nurfitrianto17@ gmail.com
}

Manuscript received: 27 January 2020. Revision accepted: 31 March 2020.

\begin{abstract}
Samiyarsih S, Fitrianto N, Azizah E, Herawati W, Rochmatino. 2020. Anatomical profile and genetic variability of sweet potato (Ipomoea batatas) cultivars in Banyumas, Central Java, based on RAPD markers. Biodiversitas 21: 1755-1766. Indonesia has developed a food consumption diversification based on local sources. Sweet potato (Ipomoea batatas) is one of the tubers of carbohydrate sources in addition to wheat, rice, corn, potatoes, and cassava. It has a wide distribution, and high cultivars diversity produces a high variation on its morphology, anatomy, and genetic modification. The objectives of this research were to investigate the anatomical profile and genetic variability of eight sweet potatoes (Ipomoea batatas) cultivars found in Banyumas, Central Java, Indonesia. Anatomical profile was observed by the embedding method and subjected to analysis of variance. DNA amplification using Random Amplified Polymorphic DNA (RAPD) method with 10 primers, namely OPA-1, OPA-2, OPA-3, OPA-4, OPA-9, OPA-11, OPA-13, OPA-15, OPA-16, and OPA18. The result of the anatomical study showed that eight sweet potato cultivars have significantly different $(\mathrm{p}<0.05)$ variation in leaf anatomical profile. RAPD primers produced 52 amplified fragments varying from 100 to $1300 \mathrm{bp}$ in size, and $90.40 \%$ of the amplification bands were polymorphic. The genetic similarity level is ranged from 0.37 to 0.93 . Two unspecific groups were forming at a coefficient of $55 \%$ from the dendrogram. The first group consisted of one cultivar, Cangkuang, and the second group consisted of seven cultivars Antin, Ungu Tua, Borobudur, Sukuh, Sari, Beta, and Kidal. The nearest relationships cultivars were Borobudur, and Ungu Tua had the highest similarity coefficient of $93 \%$, and the lowest similarity found in Cangkuang and Antin with a coefficient of $37 \%$. The range of genetic distance of eight cultivars was from 0.37-0.93. Implementation of the research would particularly useful for the identification and evaluation of the genetic improvement of sweet potato cultivars.
\end{abstract}

Keywords: Anatomy, genetic variability, Ipomoea batatas, RAPD marker

\section{INTRODUCTION}

A specific region in Indonesia has its preferred food commodities to cultivate, meaning each region has its staple food. For example in Banyumas, Central Java Province, sweet potato (Ipomoea batatas) (L.) Lam.) is one of the primary sources of carbohydrates that is quite preferred and has potential as a rice substitute. Sweet potato is an alternative rice substitute food that has high nutritional content (Dewi et al. 2019). It is suitable for production on marginal lands and has an essential role as a food (Motsa et al. 2015). Sweet potatoes cultivars have a very high diversity (Laurie et al. 2013). Hidayatun et al. (2011) reported Indonesia has 74 local cultivars originating from various regions ( 9 accessions from Banten, 18 from West Java, six from Central Java, 11 from Sumatra, one from Kalimantan, five from South Sulawesi, seven from Bali, ten from East Nusa Tenggara, one from Manokwari, and six from Wamena). In Banyumas Regency, eight cultivars were found that were cultivated based on purposive sampling in eight different districts.

Many cultivars of sweet potato causing difficulty researchers to distinguish, and therefore required a grouping of cultivars by using numerical taxonomy. The genetic approach commonly used in the form of a method includes morphological, anatomical, and molecular characters (Aguoru et al. 2015; Amoatey et al. 2016). Leaf anatomical profiles widely used to distinguish between cultivars include the epidermis, cuticle, papillae, trichomes, stomata (size and density), and the palisade layer. The structural resistance of plants to disease closely associated with anatomical characters (Dickison 2000). An example, investigating the diversity and the similarity relationship of chrysanth cultivar based on leaf anatomy (Sari et al. 2017). Anatomical structure can be used as instructions to the structural resistance of plants to pathogen attack. Various pathogens attack sweet potato plants, such as the Sphaceloma batatas fungus that causes scurvy disease (scab) (Samiyarsih et al. 2018). Anatomical profile and genetic diversity are essential information during the selection of the desired character to get superior crops.

Morpho-anatomical based identification is still widely applied (Cahyanto et al. 2017). An example, a variation analysis of three Banyumas local salak cultivars Salacca zalacca based on leaf anatomy and genetic diversity has been reported. The research showed that all salak cultivars have similar variations in leaf anatomy. It can be used for further research, such as for conservation and genetic engineering (Herawati et al. 2018). However, DNA-based molecular markers are considered stable and little 
influenced by environmental changes (Sudheer et al. 2010) DNA-based molecular markers commonly used to assess genetic diversity in plants include restriction fragment length polymorphism (RFLP), random amplified polymorphic DNA (RAPD), simple sequence repeats (SSR), amplified fragment length polymorphism (AFLP) (Costa et al. 2016), and a new class of advanced techniques using next-generation sequencing (Onda and Mochida 2016). These techniques well established, and their advantages and limitations have explored (Govindaraj et al. 2015). An older technology that is still relevant and can be used to assess genetic diversity in plants is RAPD. RAPD is a DNA-based method that has widely used for a variety of purposes, such as genetic diversity (Manurung et al. 2017), selection of cultivars of the genetic character of salttolerant (Juwarno and Samiyarsih 2017), conservation of cultivars as local genetic resources (Herawati et al. 2018) and genetic diversity-genetic variation of species (Annisa et al. 2019).

Collecting data on genetics and profile anatomy on various sweet potato cultivars of Banyumas is essential to be carried out since such data can be used as the basis of information for further research. This present study aimed to know anatomical profiles and genetic diversity of sweet potatoes cultivars in Banyumas based on leaf anatomy and Random Amplified Polymorphic DNA (RAPD) markers method. Understanding anatomical profiles and genetic diversity would be highly valuable information in preserving and the sustainable use of the germplasm.

\section{MATERIALS AND METHODS}

\section{Samples collection}

Samples collection of sweet potatoes cultivars were conducted in each sub-districts (Figure 1). Total of 40 samples of eight cultivars. Five samples of each cultivar were used to analyze the anatomical profile, and one sample of each cultivar was using to molecular analysis. Details sample site collection consist Sumpiuh (cult. Cangkuang, Sari, Beta, Kidal), Kemranjen (cult. Cangkuang, Sari, Beta), Kebasen (cult. Beta, Kidal, Ungu Tua, Antin), Rawalo (cult. Borobudur, UnguTua, Sari, Antin), Kalibagor (cult. Beta, Kidal, Antin), Purwokerto Selatan (cult. Ungu Tua, Sari, Borobudur), Karanglewas (cult. Ungu Tua, Borobudur, Beta, Kidal, Antin), Pekuncen (cult. Cangkuang, Sari, Borobudur, Sukuh, Beta, Antin). The sweet potatoes plants from each cultivar were collected and then transferred to the greenhouse of the Faculty of Biology, Universitas Jenderal Soedirman. All of the cultivars were plantlet under controlled conditions at a temperature of $30^{\circ} \mathrm{C} / 27^{\circ} \mathrm{C}$ day/night, and relative humidity of $64 \%$. From each cultivar, 2-3 leaflets were taking, then the leaflets were cut in $2 \times 2 \mathrm{~cm}$ and then put in a plastic clip bag with silica gel with a volume ratio of 1: 5 to molecular analysis (Santoso et al. 2003). Fresh leaf of the $5^{\text {th }}$ leaf from the shoot bud taken to anatomical profiles analysis (Samiyarsih et al. 2019a). Detailed the sample site and the status of eight cultivars of sweet potato are presented in Table 1 and Figure 2.

\section{Embedding for leaf anatomical profiles}

The observed anatomical profiles (paradermal and transversal section) included cuticle thickness, epidermis thickness, mesophyll thickness, stomata size, stomata, palisade ratio, and trichomes density per $1 \mathrm{~mm}^{2}$ area of the epidermis of leaves. The observation of leaf anatomical profile was performing on five months old of a plant (Samiyarsih et al. 2018). The $5^{\text {th }}$ leaf from the shoot bud was taken and cut into a $1 \mathrm{~cm}^{2}$ piece. It then was subjected to fixation in FAA solution (FAA: 10\% formalin, 5\% acetic acid, 50\% ethyl alcohol, and aquadest 35\%) for 24 hours. Preparation of leaf anatomy based on the embedding method and staining was done using safranin (1\%) in $70 \%$ alcohol. Transversal and paradermal slices using intact preparation method of fresh leaves, including (i) the number of trichomes and stomata cells; (ii) stomata and trichome density obtained from the following calculation: stomatal/trichome density=total stomata/trichomes per area of the field of view $\left(\mathrm{mm}^{2}\right)$; (iii) thickness of cuticle, epidermis, and mesophyll, the ratio of palisade (cell/mm). Observations were made with a binocular microscope, Olympus $\mathrm{CH}-20$, at 400x magnification. Measurement of anatomical profiles done using a calibrated ocular micrometer (Samiyarsih et al. 2019a).

\section{Genomic DNA isolation}

Young leaves were collected, and dried using silica gel were cleaned using alcohol 70\%. The leaf of each cultivar was placed into a plastic ziplock bag containing silica gel. The ratio of sample weight and silica gel weight was 1: 10 . Silica gels were replaced when its color changed. It was continued until the leaves were dehydrated. DNA was extracted from the dried leaf sample using the cetyltrimethylammonium bromide (CTAB) method described by Doyle and Doyle (1987) and modified by Vijay and Uttamkumar (2013). Dried leaf sample of each cultivar was placed in a cold mortar, and $500 \mu \mathrm{l}$ of extraction buffer (10\% 1M Tris-hydrochloric acid, $10 \%$ $200 \mathrm{mM}$ ethylenediaminetetraacetic acid (EDTA), 40\% 5M sodium chloride, $3 \% \mathrm{CTAB}, \beta$-mercaptoethanol, and $1 \%$ polyvinylpyrrolidone) was added, and the sample was ground. The mixture was then transferred to microtubes and incubated at $65^{\circ} \mathrm{C}$ for $15 \mathrm{~min}$. One hundred microlitres of sodium dodecyl sulfate $(20 \%)$ were added and incubated for $45 \mathrm{~min}$ at $65^{\circ} \mathrm{C}$. Ammonium acetate $(7.5 \mathrm{M} ; 150 \mu \mathrm{l})$ was added and incubated at $4^{\circ} \mathrm{C}$ for $15 \mathrm{~min}$. Chloroform isoamyl alcohol (24: 1) was added $1 \times$ mixture volume and centrifuged $(10,000 \mathrm{rpm}$ for $5 \mathrm{~min})$. The top supernatant was transferred to a new tube. The DNA present in the supernatant was precipitated in 1 volume of ethanol absolute and washed in ethanol $70 \%$. Pellet was air-dried and suspended in Tris-EDTA buffer and stored at $-20^{\circ} \mathrm{C}$.

\section{RAPD amplification analysis}

Amplification was conduct following Desai et al. (2015) method. RAPD DNA amplification was using ten primers (Table 3) and carried out using the Applied Biosystem 2720 Thermal Cycler PCR machine. The PCR reaction with a total volume of $13 \mu \mathrm{l}$, consisted of $6 \mu \mathrm{l}$ of the mixture of Go Taq polymerase master (catalog number 
M712B), one $\mu \mathrm{l}$ of stock DNA that had been diluting five times, one $\mu \mathrm{l}$ primary, and five $\mu \mathrm{l}$ ion free air. DNA amplification. The PCR amplification begins with predenaturation of the double-stranded DNA template at $94^{\circ} \mathrm{C}$ for 1 minute $(1$ cycle), then 45 cycles consisted of denaturation at $94^{\circ} \mathrm{C}$ for 1 -minute annealing at $36^{\circ} \mathrm{C}$ for 1 minute, and extension at $72^{\circ} \mathrm{C}$ for 2 minutes. This process was terminated by one cycle to complete the process during elongation (complete extension) at $72^{\circ} \mathrm{C}$ for 5 minutes.

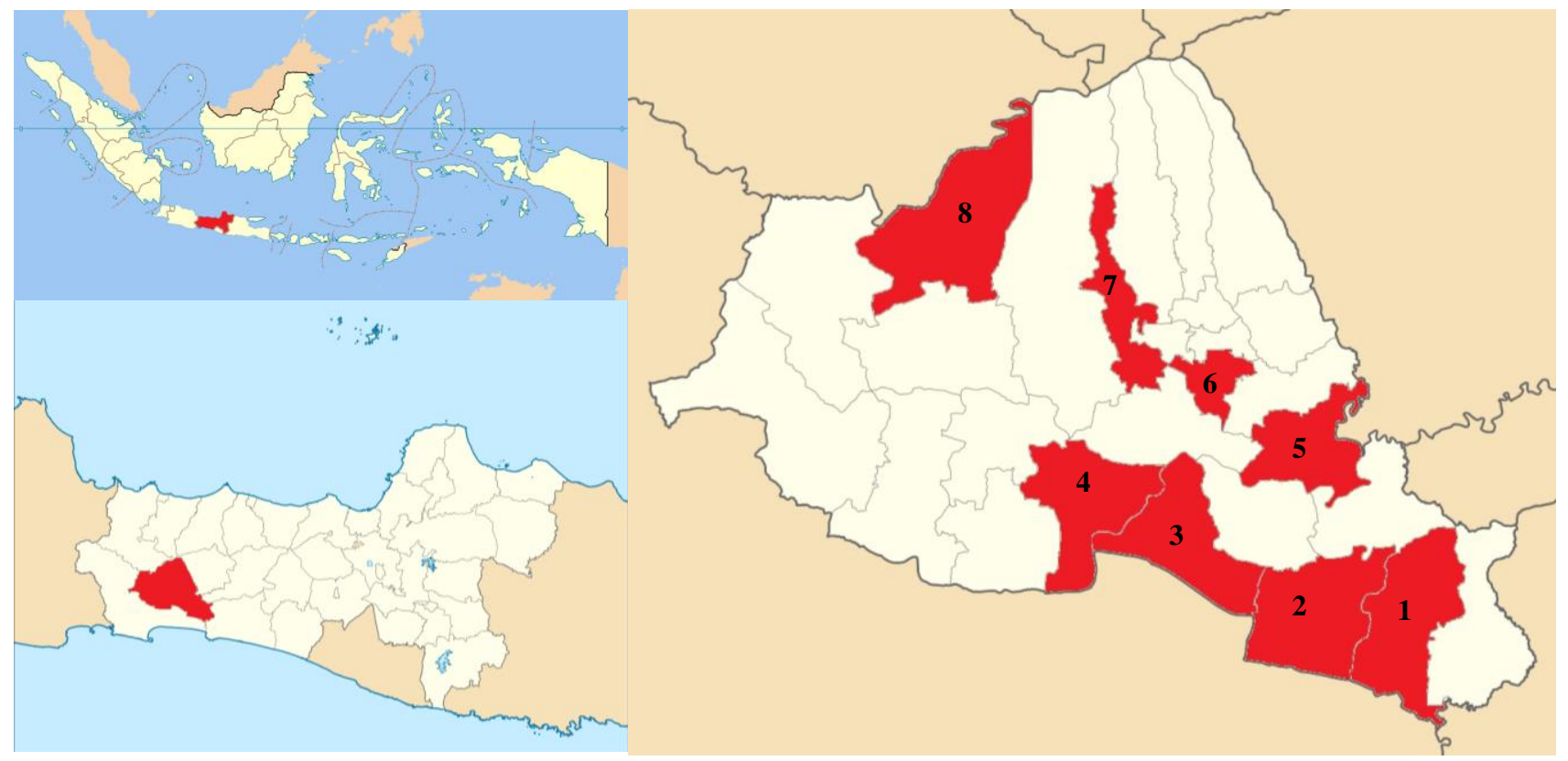

Figure 1. The selected sampling sites of the sweet potatoes area in Banyumas Regency, Central Java, Indonesia. District 1.Sumpiuh 2.Kemranjen, 3.Kebasen, 4.Rawalo, 5.Kalibagor, 6. Purwokerto Selatan, 7. Karanglewas, 8. Pekuncen

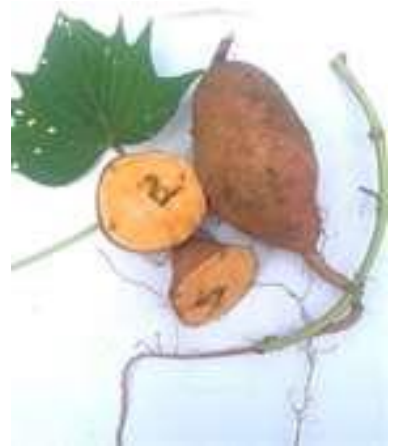

A

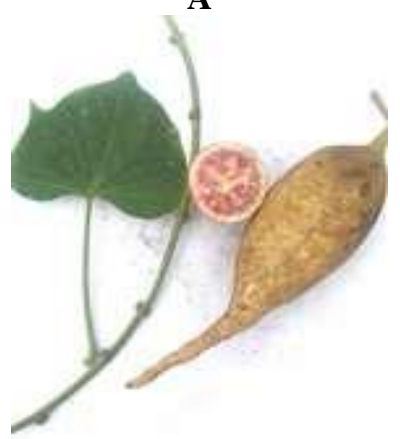

$\mathbf{E}$

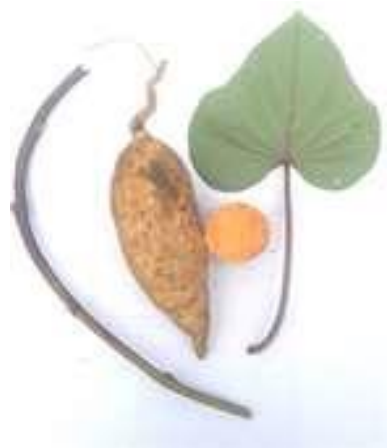

B

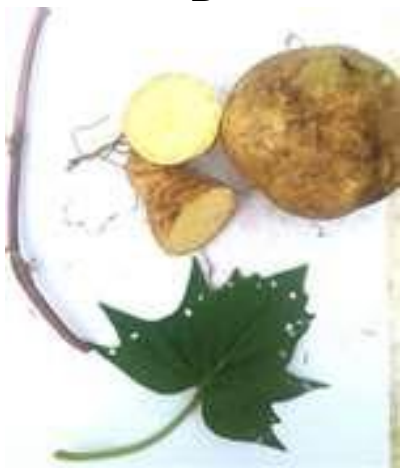

$\mathbf{F}$

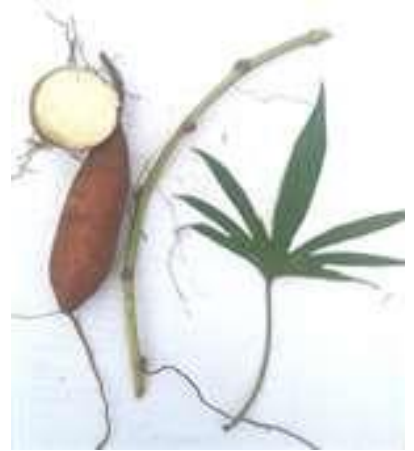

C

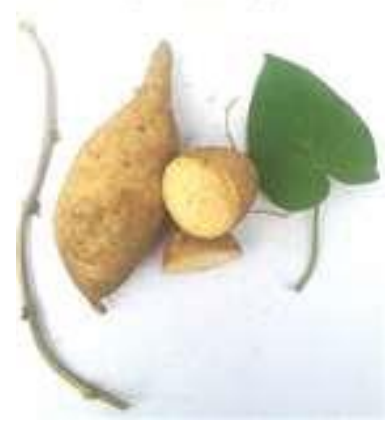

G

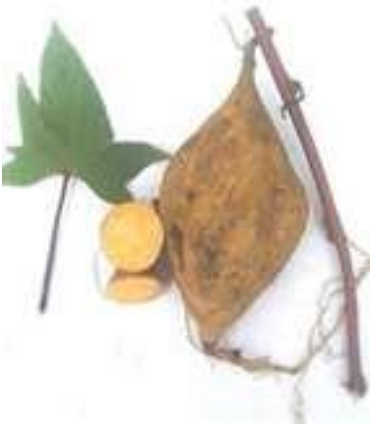

D

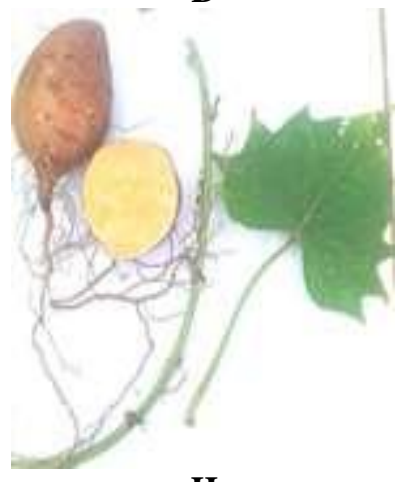

H

Figure 2. Morphology of eight sweet potato cultivars. A. Cangkuang, B. Sari, C. Kidal, D. Ungu tua, E. Antin, F. Borobudur, G. Sukuh, H. Beta 
Table 1. The sample site and status of sweet potatoes cultivar studied

\begin{tabular}{|c|c|c|c|c|}
\hline $\begin{array}{l}\begin{array}{l}\text { Sample site } \\
\text { (sub-district) }\end{array} \\
\end{array}$ & Cultivars & Status & Coordinate & $\begin{array}{r}\text { Altitude } \\
\text { (m asl.) }\end{array}$ \\
\hline Sumpiuh & Cangkuang, Sari, Beta, Kidal & Cultivated & $7^{\circ} 35^{\prime} 20.6^{\prime \prime S ~ 109 ² 1 ' 43.7 " E ~}$ & 25 \\
\hline Kemranjen & Cangkuang, Sari, Beta & Cultivated & $7^{\circ} 35^{\prime} 38.4^{\prime \prime S} 109^{\circ} 18^{\prime} 37.0^{\prime \prime} \mathrm{E}$ & 23 \\
\hline Kebasen & Beta, Kidal, Ungu Tua, Antin & Cultivated & $7^{\circ} 33^{\prime} 13.8^{\prime \prime S} 109^{\circ} 12^{\prime} 04.0 " \mathrm{E}$ & 94 \\
\hline Rawalo & Borobudur, UnguTua, Sari, Antin & Cultivated & $7^{\circ} 32^{\prime} 01.8^{\prime \prime S ~ 109 ¹ 0 ' 10.7 " E ~}$ & 28 \\
\hline Kalibagor & Beta, Kidal, Antin & Cultivated & $7^{\circ} 28^{\prime} 49.7^{\prime \prime S} 109^{\circ} 18^{\prime} 19.7^{\prime \prime E}$ & 76 \\
\hline Purwokerto Selatan & Ungu Tua, Sari, Borobudur & Cultivated & $7^{\circ} 27^{\prime} 14.2^{\prime \prime S} 109^{\circ} 14^{\prime} 29.0 " \mathrm{E}$ & 33 \\
\hline Karanglewas & Ungu Tua, Borobudur, Beta, Kidal, Antin & Cultivated & $7^{\circ} 25^{\prime} 40.4^{\prime \prime S} 109^{\circ} 12^{\prime} 23.4^{\prime \prime E}$ & 40 \\
\hline Pekuncen & Cangkuang, Sari, Borobudur, Sukuh, Beta, Antin & Cultivated & $7^{\circ} 20^{\prime} 15.1^{\prime \prime S ~ 10904 ' 04.4 " E ~}$ & 210 \\
\hline
\end{tabular}

\section{Data analysis}

Data analysis of the research consist: (i) Analysis of anatomical profile. All anatomical data collected were subject to analyses of variance, and means were separated using Duncan's multiple range test at a 5\% level of probability as well as simple percentage error for the charts and following standard deviation. (ii) The amplified RAPD were scored based on the presence or absence of fragments using binary code. Score 1 if there are fragments and score 0 if there are no fragments regardless of their intensity. A 1 $\mathrm{kb}$ DNA ladder determines the size of a DNA fragment molecule. Binary data that has been obtaining, then tested by cluster analysis using the Numerical Taxonomy and Multivariate System (NTSys) version 2.02i and Unweighted Pair Group Arithmetic Method (UPGMA) (Rohlf 1993).

\section{RESULTS AND DISCUSSION}

\section{Anatomical profile of paradermal section}

The analysis results showed that the eight observed cultivars of sweet potatoes varied greatly in anatomical profiles such as cuticle thickness, mesophyll thickness, width and length of stomata and trichomes, the density of stomata and trichomes and palisade ratio, of the observed cultivars. Analysis of variance showed that all of the sweet potatoes cultivars were significantly different $(\mathrm{p}<0.05)$ for all observed anatomical profiles (Tables 2, Figures 3-4). Epidermis cell structure as the outer part of the plant has different characters which are using to distinguish plant on the species to genera and family taxa (Ahmad et al. 2010). Paradermal section of leaves of all sweet potatoes cultivars done to observed size and density of stomata and trichomes. The highest density of adaxial and abaxial stomata was found in Cangkuang cultivars of $8 \mathrm{cell} / \mathrm{mm}^{2}$ and $17 \mathrm{cell} / \mathrm{mm}^{2}$, respectively. Trichomes have the highest density in Cangkuang cultivars as many as four cell $/ \mathrm{mm}^{2}$ in adaxial and three cell $/ \mathrm{mm}^{2}$ in abaxial. Guard cells of eight cultivars of sweet potatoes amounted to two pieces in the form of a kidney and included in the parasitic type. Guard cells are surrounding by two neighboring cells where the dividing wall of neighboring cells was parallel to the large porous stomata or parallel to the kidney-shaped cell cover. Based on the cross-section of the leave, the position of the stomata was parallel to the surface of the epidermis called the panerophore type. The stomata can be found in both of the upper layer (adaxial surface) and lower layer (abaxial surface); there was called anfistomata type (Figure 3, Table 2).

Table 2. The quantitative anatomical profile of eight sweet potatoes cultivars based on paradermal and transversal section.

\begin{tabular}{lccccccccc}
\hline Cultivars & $\begin{array}{c}\text { Cuticle } \\
\text { thickness } \\
(\boldsymbol{\mu m})\end{array}$ & $\begin{array}{c}\text { Mesophyll } \\
\text { thickness } \\
(\boldsymbol{\mu} \mathbf{m})\end{array}$ & $\begin{array}{c}\text { Width } \\
\text { of stomata } \\
(\boldsymbol{\mu m})\end{array}$ & $\begin{array}{c}\text { Length } \\
\text { of stomata } \\
(\boldsymbol{\mu m})\end{array}$ & $\begin{array}{c}\text { Density } \\
\text { of adaxial } \\
\text { stomata } \\
\left(\mathbf{c e l l} / \mathbf{m m}^{2}\right)\end{array}$ & $\begin{array}{c}\text { Density } \\
\text { of abaxial } \\
\text { stomata } \\
\left(\mathbf{c e l l} / \mathbf{m m}^{2}\right)\end{array}$ & $\begin{array}{c}\text { Density } \\
\text { of adaxial } \\
\text { trichomes } \\
\left(\mathbf{c e l l} / \mathbf{m m}^{2}\right)\end{array}$ & $\begin{array}{c}\text { Density } \\
\text { of abaxial } \\
\text { trichomes } \\
\left(\mathbf{c e l l} / \mathbf{m m}^{2}\right)\end{array}$ & $\begin{array}{c}\text { Palisade } \\
\text { ratio } \\
(\mathbf{c e l l})\end{array}$ \\
\hline Cangkuang & $4.25 \pm 1.80 \mathrm{a}$ & $115.50 \pm 0.51 \mathrm{ab}$ & $4.75 \pm 0.20 \mathrm{a}$ & $21.25 \pm 0.58 \mathrm{c}$ & $8.00 \pm 0.70 \mathrm{a}$ & $17.00 \pm 1,40 \mathrm{a}$ & $4.3 \pm 0.83$ & $3.6 \pm 0.14$ & $14 \pm 0.44 \mathrm{a}$ \\
Sari & $4.00 \pm 0.13 \mathrm{ab}$ & $112.75 \pm 0.64 \mathrm{~b}$ & $2.75 \pm 0.22 \mathrm{c}$ & $27.00 \pm 0.28 \mathrm{ab}$ & $6.00 \pm 1.22 \mathrm{ab}$ & $13.00 \pm 0.70 \mathrm{~b}$ & $2.6 \pm 0.44$ & $2.3 \pm 0.25$ & $11 \pm 0.83 \mathrm{bc}$ \\
Kidal & $3.00 \pm 1.25 \mathrm{~b}$ & $111.50 \pm 0.80 \mathrm{~b}$ & $2.75 \pm 0.25 \mathrm{c}$ & $29.50 \pm 0.41 \mathrm{ab}$ & $5.00 \pm 0.70 \mathrm{~b}$ & $11.00 \pm 0.70 \mathrm{c}$ & $2.6 \pm 0.44$ & $2.3 \pm 0.13$ & $10 \pm 0.70 \mathrm{c}$ \\
Ungu Tua & $2.75 \pm 0.20 \mathrm{bc}$ & $85.50 \pm 3.84 \mathrm{c}$ & $4.25 \pm 0.17 \mathrm{~b}$ & $26.00 \pm 0.32 \mathrm{~b}$ & $5.00 \pm 1.22 \mathrm{~b}$ & $11.00 \pm 1.58 \mathrm{c}$ & $3.3 \pm 0.44$ & $2.6 \pm 0.16$ & $7 \pm 0.70 \mathrm{~d}$ \\
Antin & $3.00 \pm 0.13 \mathrm{~b}$ & $128.50 \pm 1.91 \mathrm{a}$ & $4.00 \pm 0.13 \mathrm{~b}$ & $35.50 \pm 0.32 \mathrm{a}$ & $7.00 \pm 1.58 \mathrm{a}$ & $10.00 \pm 1.87 \mathrm{c}$ & $2.6 \pm 0.83$ & $2.3 \pm 0.16$ & $8 \pm 0.83 \mathrm{~cd}$ \\
Borobudur & $3.00 \pm 0.22 \mathrm{~b}$ & $133.50 \pm 1.22 \mathrm{a}$ & $4.50 \pm 0.13 \mathrm{a}$ & $24.00 \pm 0.30 \mathrm{bc}$ & $5.00 \pm 0.70 \mathrm{~b}$ & $14.00 \pm 1.22 \mathrm{~b}$ & $3.3 \pm 0.44$ & $2.6 \pm 0.21$ & $10 \pm 0.44 \mathrm{c}$ \\
Sukuh & $2.75 \pm 0.20 \mathrm{bc}$ & $82.50 \pm 0.48 \mathrm{c}$ & $4.50 \pm 0.20 \mathrm{a}$ & $21.50 \pm 0.28 \mathrm{c}$ & $7.00 \pm 1.22 \mathrm{a}$ & $10.00 \pm 0.70 \mathrm{c}$ & $2.6 \pm 0.83$ & $2.3 \pm 0.21$ & $12 \pm 0.70 \mathrm{~b}$ \\
Beta & $2.00 \pm 0.20 \mathrm{c}$ & $94.75 \pm 1.24 \mathrm{bc}$ & $4.00 \pm 0.20 \mathrm{~b}$ & $23.50 \pm 0.68 \mathrm{bc}$ & $6.00 \pm 1.22 \mathrm{ab}$ & $12.00 \pm 0.70 \mathrm{bc}$ & $2.3 \pm 0.70$ & $2.00 \pm 0.44$ & $9 \pm 1.92 \mathrm{~cd}$ \\
\hline
\end{tabular}


Specific anatomical characteristics have been considering to be essential data for ascertaining the phenetic relationships among cultivars in a species. Eight of sweet potatoes cultivars showed differences in anatomical profiles in terms of cuticle thickness, mesophyll thickness, length-width of stomata, stomata-trichomes density, and palisade ratio. Cangkuang has the highest different anatomical profile in cuticle thickness, density stomata-trichomes in the abaxial-adaxial side, and palisade ratio (Table 2.). An anatomical profile is closely related to genetic germplasm and product of the response to the conditions of environmental factors in which the plant grows. Ecological factors are closely related to the leaf anatomical characteristic (He et al. 2017). The density of stomata-trichomes and cuticle thickness of sweet potatoes leaves correlated with the intensity of leaf scab disease caused by pathogens Sphaceloma batatas (Pradana et al. 2017). Samiyarsih et al. (2020) reported that different cultivars of one species almost gave different structures, phytochemical compounds, and different biological activities.

Leaf anatomical traits may reflect plant adaption to environmental changes and influence ecosystem functions, as they regulate light absorption and gas exchange to some extent. The anatomical character from polluted habitat was different from unpolluted habitat. This difference was shown in leaves mesophyll thickness, cuticle thickness, stomata length size, and amount of stomata and trichome per mm 2 leaves unit area (Samiyarsih et al. 2017). Usage of nitrogen fertilizer was able to provide changes in the thickness of the cuticle, epidermis, mesophyll, and stomata density of sweet potatoes leaves (Juwarno et al. 2009). Responses to excess iron to the stomata densities were reduced on the abaxial surfaces of the sweet potatoes leaves (Adamski et al. 2012). Anatomical profile of sweet potato leaves is influenced by environmental factors, such as plumbum $(\mathrm{Pb})$ as heavy metal in air pollution are positively correlated with density, length, and width of stomata in leaves of road shade canopy trees and agriculture (Samiyarsih et al. 2019b). Stomata were found in plant organs associated with air. The distribution of stomata, length, and width pore are closely related to plant physiological processes, namely transpiration, photosynthesis, and respiration. The flexibility of the stomata pore wall allows the stomata to open and close (Sasmitamihardja and Siregar, 1996).
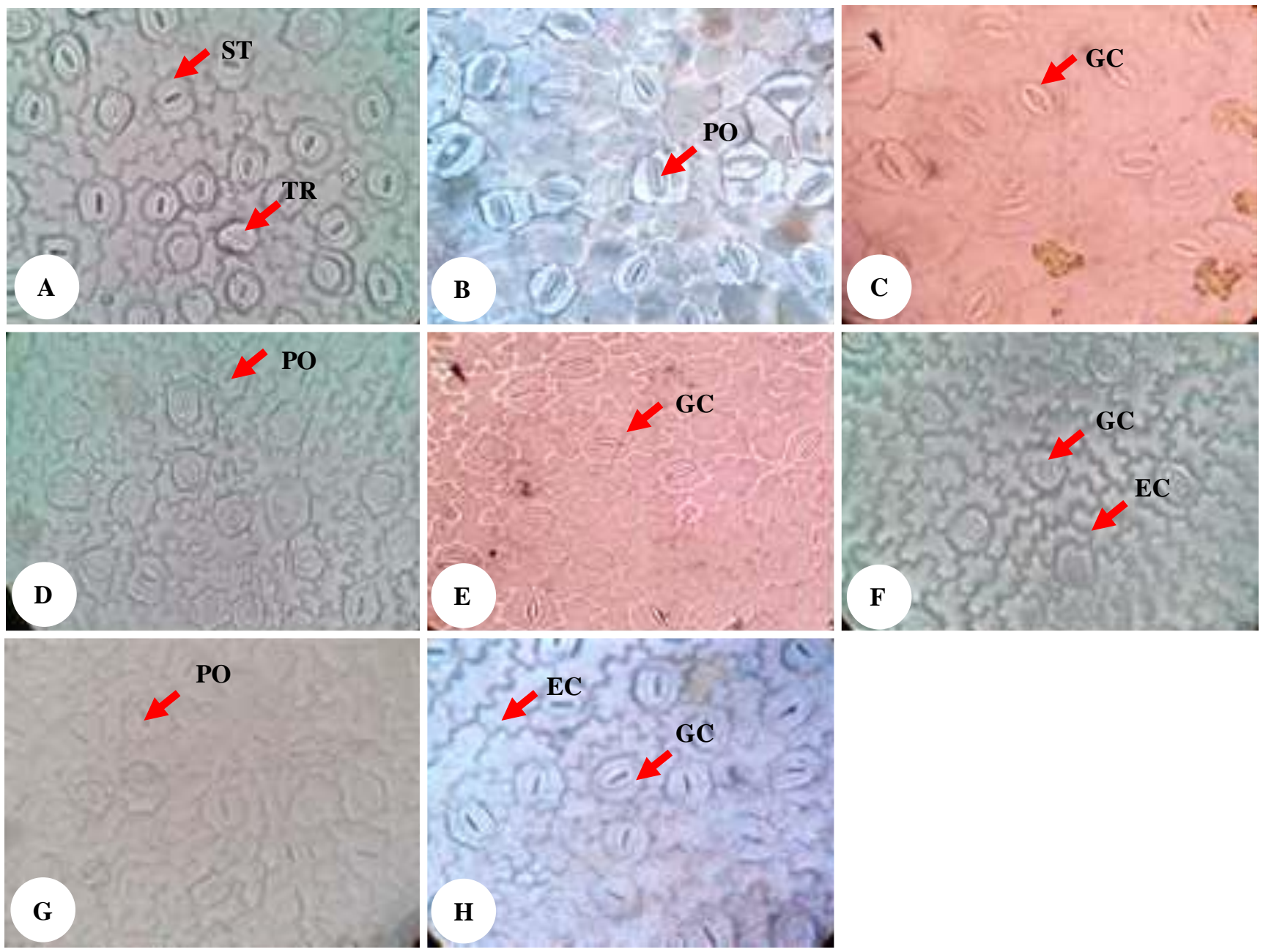

Figure 3. Paradermal section of leaves of eight sweet potatoes cultivars (at 400x magnification). A. Cangkuang, B. Sari, C. Kidal, D. Ungu tua, E. Antin, F. Borobudur, G. Sukuh, H. Beta. ST: stomata cell (parasitic type), TR: trichroma cell, PO: porus of stomata, GC: guard cell, EC: epidermal cell 

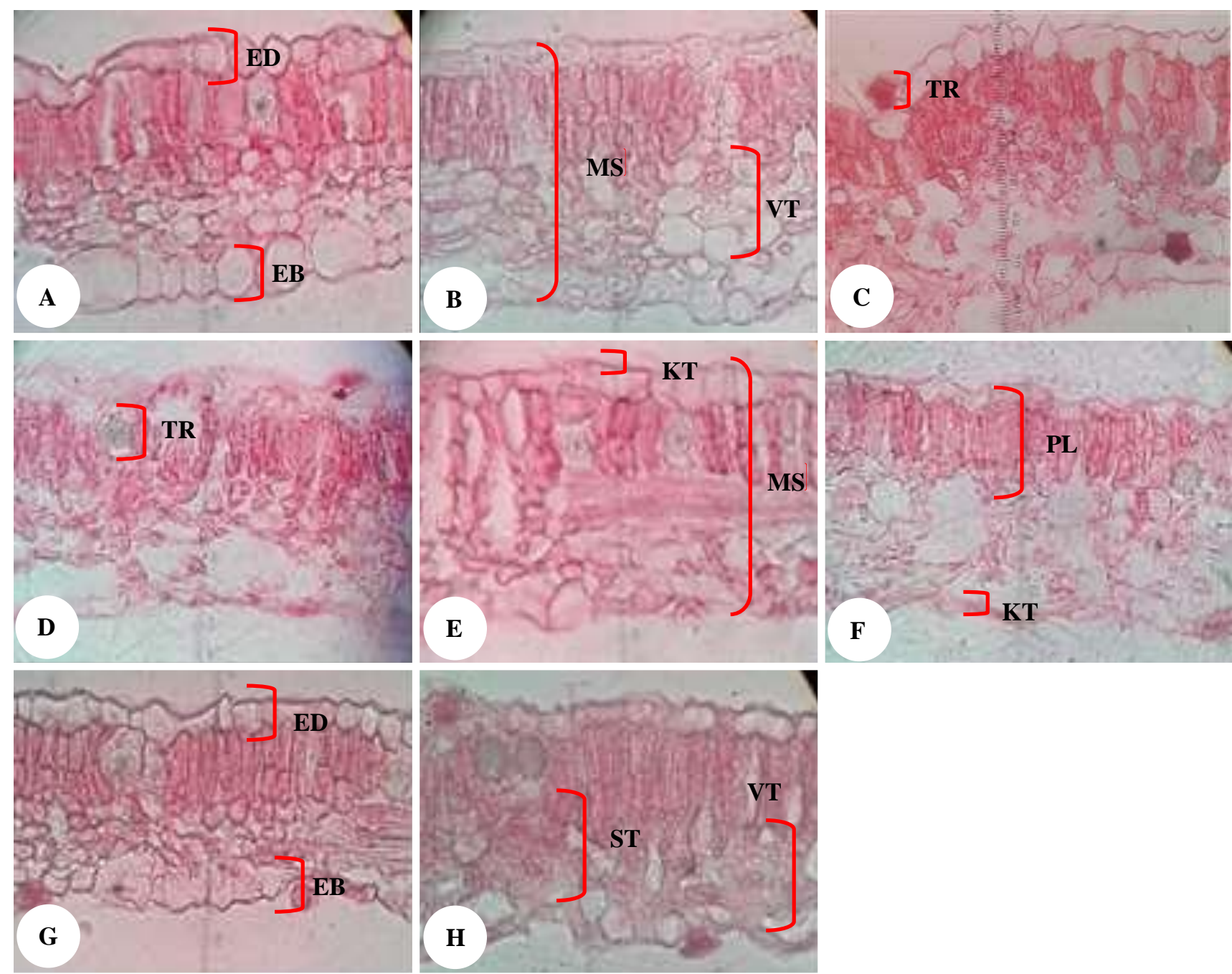

Figure 4. Anatomical of leaves cross-section of eight sweet potato cultivars (at 400x magnification). A. Cangkuang, B. Sari, C. Kidal, D. Ungu tua, E. Antin, F. Borobudur, G. Sukuh, H. Beta. ED: adaxial epidermis, EB: abaxial epidermis, MS: mesophyll tissue, TR: trichomata, KT: cuticle, PL: Palisade ratio (double layer palisade), ST: sponge tissue, VT: vesicular transport

\section{Anatomical profile of the transversal section}

The mesophyll leaves of eight sweet potatoes cultivars consisted of two-layer of palisade and few layers of sponge tissues. The leaf anatomy was composed of three types of tissue, i.e., the epidermis, mesophyll, and vascular tissue. Leaves anatomical of all cultivars show that the mesophyll was differentiated becomes palisade parenchyma and spongy parenchyma. The palisade parenchyma consists of two-layer palisade parenchyma cells. Palisade was located beneath the upper epidermal tissue with columnar-shaped cells compactly arranged and contained many chloroplasts. Palisade parenchyma forms elongated cells, arranged in stable bonds, and containing chloroplasts. Two layers of palisade cells are position at the base of the adaxial leaf of sweet potato (Figure 4.A-4.H). Sponge parenchyma tissue consists of cells that are irregular in shape with space between cells. The sponge tissue lies beneath the palisade tissue, with shaped like branches cells, appearing to be disorganized, and irregular. The sponge tissue chloroplasts are fewer than those of palisade tissue (Figure 4.F). Vascular bundles are the collateral type in which xylem coexists with the phloem (Figure 4.H). Sweet potatoes cultivar 'Cangkuang' have the best character on cuticle thickness, mesophyll thickness, stomata-trichomes density, and palisade ratio compared to other cultivars (Figures 3.A and 4.A, Table 2). Samiyarsih et al. (2019a) reported that the leaves have thick mesophyll indicated the availability of chloroplast in the palisade tissue. The high parenchyma sponge caused the high effectiveness of photosynthesis. Description of leaf anatomy is a product of the response to the conditions of the environmental factors in which the plant grows. Anatomical profiles of leaves indicated the possibility of the same genetic diversity. The anatomical profile as evidence of cultivars identity supported by genetic diversity (Ferri et al. 2009).

Each cultivar has a different thickness variation in the cuticle, mesophyll, and palisade ratio. The average mesophyll thickness of all of the cultivars is a range of $82.50-133.50 \mu \mathrm{m}$. The highest mesophyll thickness was Antin and Borobudur cultivar. Cangkuang cultivar has the highest palisade ratio of 14 cells (Figure 4.A-4.H and Table 2). Sharma et al. (2017) reported that anatomical studies 
are critical to know the structure of the organ, the cells, and the tissues that are possible to synthesize secondary metabolite compounds. Rampe et al. (2019) reported that six sweet potato cultivars in Tomohon City showed differences in anatomical characteristics in terms of stomatal density, length, and width of opened stomata pores, mesophyll thickness, and petiole cortex diameter.

Sweet potato, as a genetically diverse economic crop, offers enormous genetic resources that should be explored, maintained, utilized, and conserved. Synergistic information obtained from anatomical sources of local sweet potato cultivars in Banyumas Central Java has yielded reliable results that may call for appropriate nomenclatural assignments. Plant breeders may explore variability in sweet potato for crop improvement. This outcome thus calls for a more taxonomic audit of the $I$. batatas complexes through an anatomical profile and systematic molecular studies.

\section{DNA band formation in eight sweet potatoes cultivars}

There were 52 DNA fragments with length ranging from $100 \mathrm{bp}$ up to $1300 \mathrm{bp}$ in size. The primer that produces the highest level of polymorphism is OPA-3, OPA-4, and OPA-16 of which are 0 monomorphic bands and eight polymorphic DNA bands (Table 3). Figure 4.A (OPA-1,OPA-2), 4.B (OPA-3,OPA-4), 4.C. (OPA-9, OPA11), 4.D (OPA-13, OPA-16), 4.E (OPA-15, OPA-18) are total of 52 bands were amplified by the selected RAPD primers with an average of 5.2 bands per primer. Certain individuals show a considerable amount of amplification, whereas, in other individuals, there are only a few amplification bands. OPA-3, OPA-4, and OPA-16 primers are the primers that most amplify sweet potato DNA fragments and the primers that least amplify sweet potato fragments are OPA-1 and OPA-18 primers. They were all polymorphic, as shown in Figure 5. The results showed that DNA amplification in eight sweet potato cultivar using 10 RAPD primers where nine primers produced polymorphic bands. The results of the summary of the size and number of DNA bands of sweet potato cultivar samples can be seen (Table 3). Juwarno and Samiyarsih (2017) reported that on the RAPD markers, alleles have variation obvious if there are polymorphisms of the DNA bands. RAPD markers are not influenced by the environment, analysis of diversity based on RAPD; therefore, it reflects the genetic diversity of the population studied. The existence of high genetic diversity found in the population studied can be caused by different sources of seed origin or due to the influence of natural mutations and crosses (Vidal et al. 2019).

\section{Percentage of polymorphisms DNA}

PCR-RAPD amplification using ten primers produce a diverse genetic variation, marked by the DNA bands formation in eight sweet potato cultivars with varying sizes in each cultivar. The monomorphic bands (9.6\%) and 47 polymorphic DNA bands $(90.4 \%)$. The scoring results of each primer generate DNA polymorphism data shown in Table 2. Total 52 DNA bands amplified, with 47 polymorphic DNA fragments and five monomorphic DNA fragments. RAPD primers amplified bands with a size range of $100 \mathrm{bp}$ (OPA-3) to $1300 \mathrm{bp}$ (OPA-13 and OPA16). They amplified 47 polymorphic bands and 52 total numbers of bands with an average of 4.7 and 5.2, respectively. Dendrogram constructed from RAPD data showed that Jaccard's similarity range from 0.51 to 0.93 (Figure 6.). The average of the polymorphic DNA percentage is greater than $50 \%$, so these eight primers have a high polymorphism level. It can be used in the genetic variation analysis to compare between cultivars. Overall results of data in Table 3, the percentage of polymorphic DNA above $50 \%$ is found in OPA-1 (100\%), OPA-2 (100\%), OPA-3 (100\%), OPA-4 (100\%), OPA-9 (80\%), OPA-11 (100\%), OPA-13 (100\%), OPA-16 (100\%) primers, while percentage of polymorphic DNA in the below $50 \%$ is found in OPA-15 primer $(50 \%)$ and OPA-18 primer $(0 \%)$. The results showed that the RAPD markers used had high levels of polymorphism. On average, each primer produces 9.5 bands. OPA-3, OPA-4, and OPA-16 gave the highest polymorphic bands (8), while the lowest number of polymorphic bands (1) was observed in OPA-15 (Table 3). Scoring the polymorphism was started by assuming the band produced by the primers as putative locus. The DNA bands are in polymorphic patterns when the appearance in the particular locus all samples' templates are $\leq 95 \%$ and vice versa when they appear on $>95 \%$ are called monomorphic (Sasongko et al. 2019). Overall, the polymorphic level of the primers used in this study was considered good with a range between $50 \%$ to $100 \%$ polymorphic bands. Subositi and Widiyastuti (2013) stated that polymorphisms mean as genome complexity leads to genetic variability among the samples. Nine primers (OPA-1, OPA-2, OPA-3, OPA-4,OPA-11, OPA13 , and OPA-16) produced $100 \%$ polymorphic patterns (Table 3) and so-called performed high polymorphisms. As stated by Poerba and Yuzammi (2008), highly polymorphisms of the primers tested were $\geq 50 \%$.

\section{Genetic variability of sweet potatoes cultivars}

Primers were used in this study have a proportion of $\mathrm{G}+\mathrm{C}$ between $60-70 \%$ (Table 2), so it is good enough to be used for the PCR-RAPD process. Condition this is following Newton \& Graham's (1997), that success DNA genome amplification using the PCR-RAPD technique was determined by order of the primary bases used. Suitable $\mathrm{G}+\mathrm{C}$ base content in the primary sequence used for PCRRAPD for organisms eukaryotes should contain a proportion of $\mathrm{G}+\mathrm{C}$ of $60 \%$. Consistent with the statement of Poerba and Yuzammi (2008) that the successful amplification of genomic DNA using the PCR-RAPD technique is also determining by the base sequence of the primers used and the quality or content of the primer in each reaction. RAPD markers obtained with random amplification of DNA segments from a single arbitrary primer. Primers used are typical of $10 \mathrm{bp}$. The $\mathrm{G}+\mathrm{C}$ content of bases in primer sequences used for PCR-RAPD should contain more than $40 \% \mathrm{G}+\mathrm{C}$ bases (usually containing 50$80 \% \mathrm{G}+\mathrm{C}$ ) and does not contain palindromic sequences (Premkrishnan and Arunachalam, 2012). Different genetic distances were found in among the eight sweet potato cultivars based on these ten of DNA markers. The genetic 
distance based on RAPD markers were ranging from 0.37 to 0.93 (Table 4). Avivi et al. (2019) reported that the molecular markers data function in determining the level of difference and similarity of each cultivar. The lower the coefficient of similarity between cultivars indicates that the farther relationship between cultivars so that it will have a high heterosis effect when crossed. The results obtained demonstrated that the RAPD approach has considerable potential for the identification and discrimination of different sweet potato cultivars.
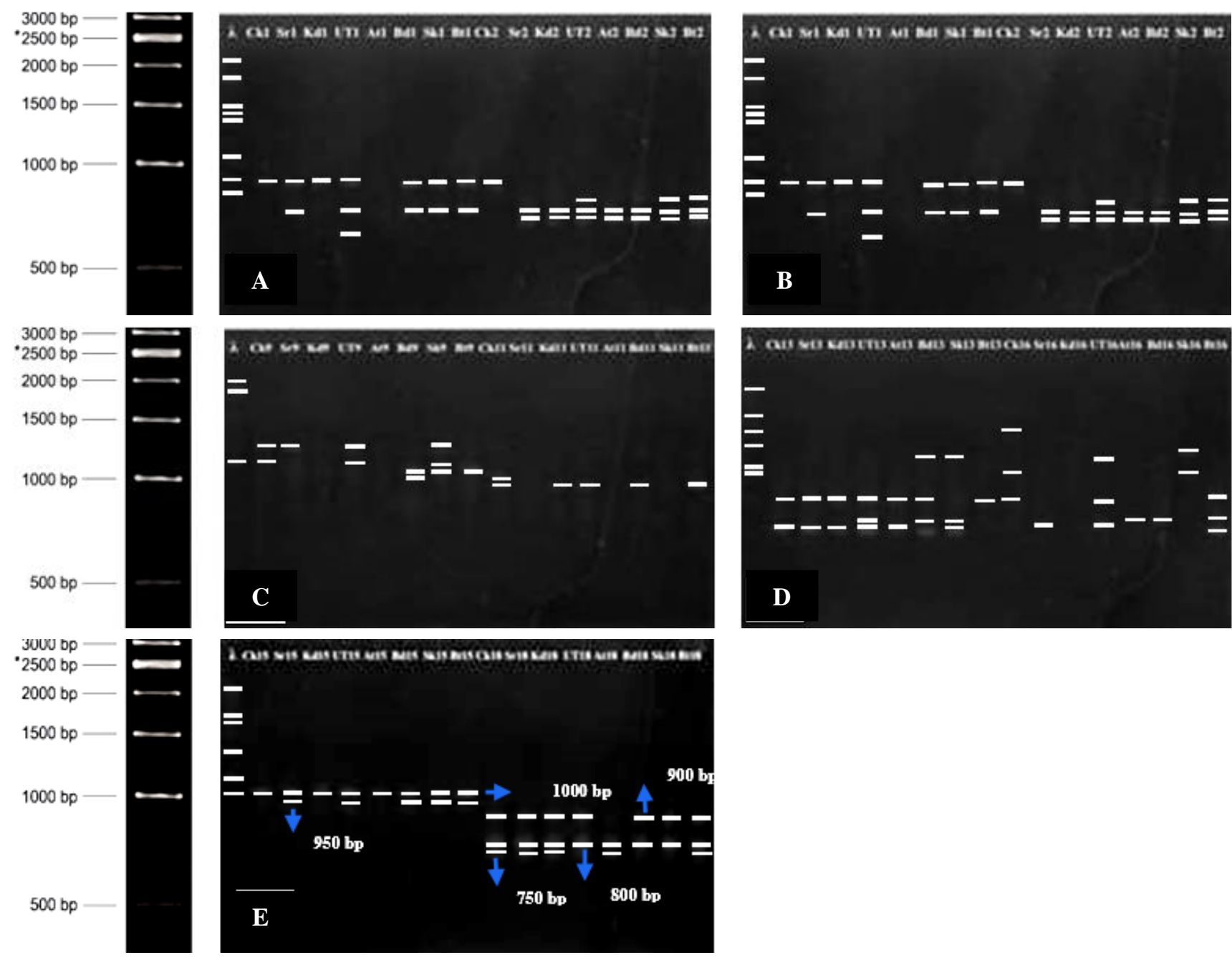

Figure 5. Amplified DNA of eight sweet potatoes cultivars based on 10 RAPD primers, namely (A) OPA-1, OPA-2. (B) OPA-3, OPA4. (C) OPA-9, OPA-11. (D) OPA-13, OPA-16. (E) OPA 15, OPA 18. Note: $\lambda=$ marker $1 \mathrm{~kb}, \mathrm{Ck}=\mathrm{Cangkuang}, \mathrm{Sr}=\mathrm{Sari}, \mathrm{Kd}=\mathrm{Kidal}$, $\mathrm{UT}=$ Ungu Tua, At= Antin, Bd= Borobudur, $\mathrm{Sk}=$ Sukuh, Bt= Beta)

Table 3. DNA polymorphisms detected on nine RAPD primers for eight sweet potatoes cultivars

\begin{tabular}{|c|c|c|c|c|c|c|c|}
\hline Primer & $\begin{array}{c}\text { Sequence } \\
\left(5^{\prime}-3^{\prime}\right)\end{array}$ & $\begin{array}{l}\text { Locus } \\
\text { (bp) }\end{array}$ & $\begin{array}{c}\text { G+C } \\
\text { Content }(\%)\end{array}$ & $\begin{array}{c}\text { Number of } \\
\text { DNA } \\
\text { fragments }\end{array}$ & $\begin{array}{c}\text { Polymorphic } \\
\text { DNA band }\end{array}$ & $\begin{array}{l}\text { Monomorphic } \\
\text { DNA band }\end{array}$ & $\begin{array}{c}\text { Percentage of } \\
\text { Polymorphic } \\
\text { DNA bands (\%) }\end{array}$ \\
\hline OPA-1 & CAGGCCCTTC & $250-750$ & 70 & 2 & 2 & 0 & 100 \\
\hline OPA-2 & TGCCGAGCTG & $200-720$ & 70 & 4 & 4 & 0 & 100 \\
\hline OPA-3 & AGTCAGCCAC & $100-1050$ & 60 & 8 & 8 & 0 & 100 \\
\hline OPA-4 & AATCGGGCTG & $200-1250$ & 60 & 8 & 8 & 0 & 100 \\
\hline OPA-9 & GGGTAACGCC & $250-1150$ & 70 & 5 & 4 & 1 & 80 \\
\hline OPA-11 & CAATCGCCGT & $250-1150$ & 60 & 5 & 5 & 0 & 100 \\
\hline OPA-13 & CAGCACCCAC & $200-1300$ & 70 & 7 & 7 & 0 & 100 \\
\hline OPA-16 & AGCCAGCGAA & $200-1300$ & 60 & 8 & 8 & 0 & 100 \\
\hline OPA-15 & TTCCGAACCC & $650-750$ & 60 & 2 & 1 & 1 & 50 \\
\hline OPA-18 & AGGTGACCGT & $200-600$ & 60 & 3 & 0 & 3 & 0 \\
\hline Total & & & & $52(100 \%)$ & $47(90.4 \%)$ & $5(9.6 \%)$ & \\
\hline
\end{tabular}


A dendrogram based on UPGMA analysis with RAPD data (similarity matrix) is illustrating in Figure 6. Almost all cultivars stand alone at a $93 \%$ relationship level. The level of genetic relationship between the two genotypes tested ranged from 0.51 to 0.93 , meaning that all eight genotypes had a close relationship level to a distant relative. Based on the dendrogram, all genotypes can distinguish between one genotype cultivar and another. The high genetic distance indicated that the relationship between both cultivars was far enough and that the small genetic distance value suggested that the relationship was close. Cluster analysis was performing using the UPGMA method to produce a dendrogram. If a straight line is drawn that cuts the dendrogram at a 55\% relationship level, two groups are formed. Namely, Cluster I consisting of one cultivar, Cangkuang, and Cluster II was consisting of seven in other cultivars: Antin, Sari, Kidal, Borobudur, Ungu Tua, Sukuh and Beta. Major clusters show genetic variation among the cultivars that form sub-clusters. Borobudur's cultivar shows the closest relationship and Ungu Tua with a similarity coefficient of $93 \%$. Avivi et al. (2019), the molecular markers data function in determining the level of difference and similarity of each cultivar. In contrast, cultivars that have the most distant relationship are Cangkuang with Antin was similarity coefficients reaching $37 \%$ (Table 4, Figure 6).

The CTAB method has been successfully used for DNA extraction from sweet potato leaves. RAPD marker analysis is widely used for the detection of genetic diversity and classification of the germplasm of many organisms. Permatasari et al. (2018) reported that the genetic similarity of an organism could be determined by DNA analysis using a specific molecular marker application. Non-specific primers could lead to the amplification of other areas of the genome that were not targeted, or otherwise, there were no amplified genomic regions. The difference in cultivars can be seen from the number of the band, the band thickness, and mobility (Figure 5A-5E). Cluster analysis carried out using RAPD marker data showed that the genetic material studied was grouped into two main clusters.

The different primers are using to amplify different numbers of genotypes. Estimation of genetic diversity among and within crops is crucial in breeding and conservation of genetic resources. RAPDs have been showing to be an effective method for studying genetic diversity in many plants such as hybrid species of Nepenthes hookeriana (Yulita and Mansur 2012), Capsicum annuum (Peeraullee and Ranghoo-Sanmukhiya 2013), Salacca zalacca (Herawati et al. 2018), and Carica papaya (Sabara and Vakharia 2018). The current results showed that sweet potatoes cultivars in Banyumas had a variety of distant relationships. Sweet potatoes locals cultivars could be essential genetic resources for sweet potato breeding and plant diseases.

The genetic distance of the similarity matrix (Table 4, Figure 6), Borobudur's cultivar, shows the closest relationship and Ungu Tua with a similarity coefficient of 0.93. In contrast, cultivars that have the most distant relationship are Cangkuang' with Antin was similarity coefficients reaching 0.37 . Based on the analysis results, the Cangkuang cultivar has the characteristics in the anatomical profile that are most different from other cultivars so that they form their group (Cluster 1) on the formed dendrogram. This study shows that there is a relationship between the anatomical characteristics of leaves with molecular characters. Fajriani et al. (2012) reported that there is the extensive genetic diversity of sweet potato cultivars for the leaves, vines length, storage root number, storage root weight, storage root length, storage root diameter, harvest index, dry matter content of storage roots, and storage root yield. Mohammed et al. (2015), found to be useful in assessing diversity, and specific markers obtained for cultivars could be used for their identification. The character which has a broad genetic diversity would also have a wide diversity of phenotypes. Almost the same results are showing by some previous research on sweet potato. In the previous research of Solankey et al. (2015), cluster analysis of sweet potatoes cultivars divided twenty genotypes into two main groups, indicating a genetic relationship among accessions.

The dendrogram showed clear grouping ancestrally related sweet potato cultivars. The analysis of RAPD generated polymorphic bands showed variations in the number, length, and intensity of the resulting bands. Yang et al. (2015), PCR-RAPD are widely distributed throughout the eukaryotic genomes in coding and non-coding regions. Their random genome distribution and use with low quality DNA have resulted in extensive use in the determination of genetic diversity, germplasm fingerprinting, genetic linkage mapping, and phylogenetic studies of sweet potato. Genotypes that have many similarities in character means having a close relationship, while genotypes which have little or no similarity in character, means having a distant relationship (Jan et al. 2012). Genetic factors influenced the characters found in sweet potato genotypes. Phenotypic in 30 sweet potato genotypes found at the Politeknik Negeri Lampung has an extensive genetic and phenotypic diversity and high heritability (Dewi et al. 2019).

The anatomical profile helps in the identification of plant taxa when the floral characters are unavailable or similar. Micro-anatomical features are relevant taxonomic tools in separating sweet potato cultivars in Banyumas Regency. It was concluded that a comprehensive anatomical profile is advantageous in order to understand all aspects of this variation. RAPD markers for evaluated diversity analysis was highly reproducible, revealed sufficient genetic variability, and a high level of genetic polymorphism. These would be further useful for the evaluation of the genetic improvement of sweet potato cultivars. Rahajeng et al. (2017), both morphological and molecular markers, have been using to assess the genetic diversity of sweet potato. The most important activity in the sweet potato breeding program is the selection activity, and the selection activity has an essential role in selecting and determine the genotypes which are compatible with the purpose of breeding. So the success of the breeding program is determined by the effectiveness of selection activities. 
Table 4. Genetic distance among eight sweet potatoes cultivars based on a matrix of similarity using the UPGMA method

\begin{tabular}{lcccccccc}
\hline \multicolumn{1}{c}{ Cultivar } & Cangkuang & Sari & Kidal & Ungu Tua & Antin & Borobudur & Sukuh & Beta \\
\hline Cangkuang & 1.00 & & & & & & & \\
Sari & 0.61 & 1.00 & & & & & & \\
Kidal & 0.57 & 0.81 & 1.00 & & & & \\
Ungu Tua & 0.53 & 0.81 & 0.79 & 1.00 & & & \\
Antin & $\mathbf{0 . 3 7}$ & 0.60 & 0.59 & 0.63 & 1.00 & & \\
Borobudur & 0.59 & 0.83 & 0.77 & $\mathbf{0 . 9 3}$ & 0.58 & 1.00 & 1.00 & \\
Sukuh & 0.49 & 0.69 & 0.72 & 0.74 & 0.58 & 0.82 & 0.70 & 1.00 \\
Beta & 0.44 & 0.71 & 0.68 & 0.76 & 0.48 & 0.75 & \\
\hline
\end{tabular}

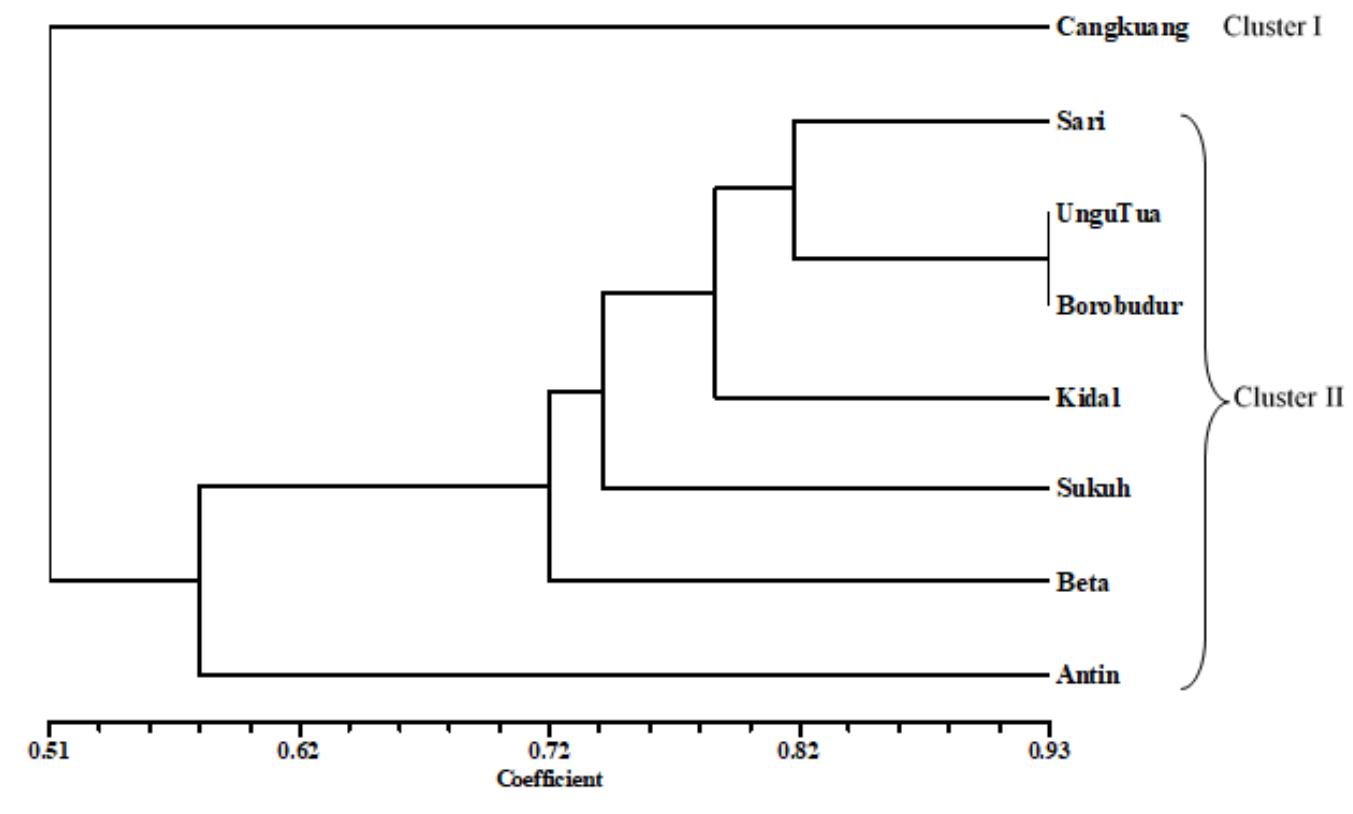

Figure 6. Dendrogram generated using UPGMA cluster analysis among eight sweet potatoes cultivars

RAPD molecular marker is still useful to identify a genetic relationship between cultivars, which are originating from the same ancestry. The findings of the present investigations indicated high genetic diversity in sweet potatoes cultivars of Banyumas Regency, which could be used in bean breeding programs. Genetic diversity of sweet potato was determined based on the relationship of genetic similarity between one individual plant and another by comparing DNA banding patterns resulting from PCR amplification.

In conclusion, the analysis of variance showed that all of the sweet potatoes cultivars were significantly different $(p<0.05)$ for all observed anatomical profiles. Nine out of ten primers could detect polymorphic bands (90.4\%). The genetic similarity level ranged from 0.37 to 0.93 . Two unspecific groups were forming at a coefficient of $55 \%$ from the dendrogram, which is resulting from UPGMA on NTSys pc-2.02i program. The first cluster consisted of one cultivar (Cangkuang). The second cluster consisted of seven cultivars (Antin, Ungu Tua, Borobudur, Sukuh, Sari, Beta, and Kidal). The nearest relationships were cultivar
Borobudur, and Ungu Tua had the highest similarity coefficient, with a percentage of $93 \%$. The lowest similarity coefficient was found between Cangkuang and Antin, with a percentage of $37 \%$, so both had the farthest relationships. Cultivars of each group indicated the possibility of the same genetic resource. The results of the present investigations would be mainly used for identification and useful for the evaluation of the genetic improvement of sweet potato cultivars.

\section{ACKNOWLEDGEMENTS}

The author thanks the Ministry of Research, Technology, and Higher Education of the Republic of Indonesia and Research and Public Service Institute of Jenderal Soedirman University for funding this research through Institution Research-scheme. We also thank the farmers of sweet potato in Banyumas Regency, who helped provide the sample material. 


\section{REFERENCES}

Adamski JM, Danieloski R, Deuner S, Braga EJ, Castro LA, Peters JA 2012. Responses to excess iron in sweet potato: impacts on growth, enzyme activities, mineral concentrations, and anatomy. Acta Physiol Plant 34 (5): 1827-1836.

Aguoru CU, Uhia P, Olasan JO. 2015. Varietal characterization and taxonomic evaluation of sweet potato (Ipomoea batatas) using macroand micromorphological evidence. Open Access Libr J 2: e1757. DOI: $10.4236 /$ oalib.1101757.

Ahmad K, Khan MA, Ahmad M, Shaheen N, Nazir A. 2010. Taxonomic diversity in epidermal cells of some sub-tropical plant species. Intl J Agric Biol 12 (1): 115-118.

Amoatey HM, Sossah FL, Ahiakpa JK, Quartey EK, Appiah AS, Segbefia MM. 2016. Phenotypic profiles of different accessions of swee potato (Ipomoea batatas L. Lam) in the coastal savanna agroecological zone of Ghana. Afr J Agric Res 11 (26): 2316-2328.

Annisa, Hafzari R, Setiawati T, Irawan B, Kusmoro J. 2019. Evaluation of RAPD markers for molecular identification of five bamboo genera from Indonesia. Folia Forestalia Polonica 61 (4): 255-266.

Avivi S, Suliswanto EN, Restanto DP, Miswar, Syamsunihar A Soeparjono S, Hartatik S. 2019. Morphological Diversity and Molecular RAPD Markers of Sugarcane Mutane (Saccharum officinarum L.) in Inundation Tolerance. Agrivita J Agric Sci 41 (2): 221-229.

Cahyanto T, Sopian A, Efendi M, Kinasih I. 2017. Grouping of Mangifera indica L. cultivars of Subang West Java by leaves morphology and anatomy characteristics. Biosaintifika 9 (1): 156-167.

Costa R, Pereira G, Garrido I, Tavares-de-Sousa MM, Espinosa F. 2016 Comparison of RAPD, ISSR, and AFLP Molecular Markers to Reveal and Classify Orchardgrass (Dactylis glomerata L.) Germplasm Variations. PLoS ONE $11 \quad$ (4): e0152972. DOI 10.1371/journal.pone.0152972

Desai P, Gajera B, Mankad M, Shah S, Patel A, Patil G, Kumar N. 2015. Comparative assessment of genetic diversity among Indian bamboo genotypes using RAPD and ISSR markers. Mol Biol Rep 42 (8): 1265-1273.

Dewi R, Utomo SD, Kamal M, Timotiwu PB, Nurdjanah S. 2019. Genetic and phenotypic diversity, heritability, and correlation between the quantitative characters on 30 sweet potato germplasms in Lampung, Indonesia. Biodiversitas 20 (2): 380-386.

Dickison WC. 2000. Integrative Plant Anatomy. Harcout Academic Press. Elsevier (USA)

Fajriani N, Suliartini NWS, Boer D, Suaib, Wijayanto T. 2012. Genetic variability of important agronomic trait of some local sweet potato clones are cultivated in the villages of Suburbs Kendari. Berkala Penelitian Agronomi 1 (1): 93-101. [indonesian]

Ferri G, Alu M, Corradini B, Beduschi G. 2009. Forensic botany: species identification of botanical trace evidence using a multigene barcoding approach. Intl J Legal Med 123 (5): 395-401.

Govindaraj M, Vetriventhan M, Srinivasan M. 2015. Importance of genetic diversity assessment in crop plants and its recent advances: an overview of its analytical perspectives. Membr Water Treat 8 (5) 449-462.

He N, Liu C, Tian M, Li M, Yang H, Yu G, Hou J. 2017. Variation in leaf anatomical traits from tropical to cold-temperate forests and linkage to ecosystem functions. Func Ecol 32 (1): 10-19.

Herawati W, Amurwanto A, Nafi'ah Z, Ningrum AM, Samiyarsih S 2018. Variation analysis of three Banyumas local salak cultivars (Salacca zalacca) based on leaf anatomy and genetic diversity. Biodiversitas 19: 119-125

Hidayatun N, Chaerani C, Utami DW. 2011. Sidik jari DNA 88 plasma nutfah ubi jalar di Indonesia berdasarkan delapan penanda SSR. Jurnal AgroBiogen 7 (2): 119-127 [Indonesian]

Juwarno, Samiyarsih S. 2017. Anatomical and molecular responses of soybean (Glycine $\max$ (L.) Merr.) due to salinity stresses. Molekul 12 (1): 45-52.

Juwarno, Sumarsono S, Samiyarsih S. 2009. The Effects of nitrogen fertilizer dosages on anatomical characters of Ipomoea batatas L. leaf. Majalah Ilmiah Biologi Biosfera 26 (1): 30-34.

Laurie SM, Calitz FJ, Adebola PO, Lezar A. 2013. Characterization and evaluation of South African sweet potato (Ipomoea batatas (L.) Lam) landraces. S Afr J Bot 85: 10-16.

Manurung J, Siregar IZ, Kusmana C, Dwiyanti FG. 2017. Genetic variation of the mangrove species Avicennia marina in heavy metal polluted estuaries of Cilegon Industrial Area, Indonesia. Biodiversitas 18 (3): 1109-1115.

Mohammed W, Ali S, Shimelis B, Burga S. 2015. Genetic diversity of local and introduced sweet potato [Ipomoea batatas (L.) Lam.] collections for agro-morphology and physicochemical attributes in Ethiopia. Sci Technol Arts Res J 4 (1): 9-19.

Motsa NM, Modi AT, Mabhaudhi T. 2015. Sweet potato (Ipomoea batatas L.) as a drought-tolerant and food security crop. South Africa J Sci 111 (11): 1-8.

Newton CA, Graham A. 1997. PCR. Bios Scientific Publishers Ltd, Oxford.

Onda Y, Mochida K. 2016. Exploring genetic diversity in plants using high-throughput sequencing techniques. Curr Genom 17 (4): 358-367.

Peeraullee N, Ranghoo-Sanmukhiya VM. 2013. Assessment of genetic diversity in local chilli (Capsicum annuum) varieties in Mauritius. Intl J Agric Biol 15 (5): 891-896.

Permatasari F, Mercuriani IS, Yulianti E. 2018. Genetic similarity analysis of Rhynchostylis retusa (L.) Blume orchids using OPA 15 and OPA 03 RAPD marker. AIP Conf Proc 2021: 050005. DOI: $10.1063 / 1.5062755$

Poerba YS, Yuzammi. 2008. Estimation of genetic variation of Amorphophallus titanum Becc. Based on RandomAmplified Polymorphic DNA. Biodiversitas 9 (2): 103-107.

Pradana AW, Samiyarsih S, Muljowati JS. 2017. Korelasi karakter anatomi daun ubi jalar (Ipomoea batatas L.) kultivar tahan dan tidak tahan terhadap intensitas penyakit kudis daun. Scripta Biologica 4 (1) [Indonesian]

Premkrishnan BV, Arunachalam V. 2012. In silico RAPD priming sites in expressed sequences and iSCAR markers for oil palm. Comp. Funct. Genomics, 12 (1): 1-5.

Rahajeng W, Rahayuningsih SA. 2017. Agronomic performance, variance component, and diversity of sixty-two sweet potato accessions. Biodiversitas 18: 95-100.

Rampe HL, Umboh SD, Siahaan R, Maabuat PV. 2019. Anatomical characteristics of stomata, mesophyll, and petiole of six varieties sweet potatoes (Ipomoea batatas L.) after organic fertilizer induction. IOP Conf. Series: Mater Sci Eng 567: 012044. DOI: 10.1088/1757899X/567/1/012044

Rohlf FJ. 1993. Numeric taxonomy and multivariate analysis system. NTSYS-pc. Stony Brook: New York

Sabara P, Vakharia D. 2018. Genetic diversity study in papaya (Carica papaya L.) cultivars using RAPD and ISSR markers. Indian J Biotechnol 17: 101-109.

Samiyarsih S, Brata T, Juwarno. 2016. Karakter anatomi daun tumbuhan mangrove akibat pencemaran di hutan mangrove Kabupaten Cilacap. Biosfera 33 (1): 31-36. [Indonesian]

Samiyarsih S, Fitrianto N, Proklamasiningsih E, Juwarno, Muljowati JS. 2020. Phytochemical diversity and antimicrobial properties of methanol extract of several cultivars of Catharanthus roseus using GC-MS. Biodiversitas 21 (4): 1332-1344.

Samiyarsih S, Juwarno, Muljowati JS. 2018. The structural resistance's anatomy of sweet potato leaves to fungal pathogen Sphaceloma batatas. Biosaintifika 10 (1): 131-137.

Samiyarsih S, Naipospos N, Palupi D. 2019a. Variability of Catharanthus roseus based on morphological and anatomical characters, and chlorophyll contents. Biodiversitas 20 (10): 2986-2993.

Samiyarsih S, Santoso S, Lestari S, Ardiyuda D, Fitrianto N. 2019b. Ability of Road Shade Plants As Pb Absorbent in Jalan Jenderal Soedirman Purwokerto. In International Conference of Mangroves and Its Related Ecosystems 2019. Faculty of Biology, University of Jenderal Soedriman, Purwokerto, 19-23 August 2019 [Indonesian]

Santoso J, Saleh GB, Saleh NM, Napis S. 2003. Preservation of fresh leaf samples from long-distance field collection for DNA extraction. From Peas to Chips.The Globalization of Genetics. Proceeding of the 5th National Congress on Genetic, Kuala Lumpur, 25-27 March 2003.

Sari, IA, Sukarsa, Samiyarsih S. 2017. Analisis Fenetik Kultivar Krisan (Chrysanthemum morifolium Ramat.). Majalah Ilmiah Biologi Biosfera 33 (2): 52-59 [Indonesian]

Sasmitamihardja D, Siregar A. 1996. Plant Physiology. Biology Department, Bandung Institute of Technology, Bandung. [Indonesian]

Sasongko ND, Samiyarsih S, Juwarno. 2019. Genetic variation among the scabies-infested sweet potato cultivars. Intl J Curr Res 11 (7): 51155120 .

Solankey SS, Singh PK, Singh RK. 2015. Genetic diversity and interrelationship of qualitative and quantitative traits in sweet potato. Intl J Veget Sci 21 (3): 236-248. 
Subositi D, Widiyastuti Y. 2013. Keragaman Genetik Aksesi Ekinase (Echinacea Purpurea (L.) Moench) Hasil Seleksi Massa Tahun I Melalui Analisis RAPD. Buletin Kebun Raya 16 (2): 93-100 [Indonesian]

Sudheer DVN, Mastan SG, Rahman H, Reddy MP. 2010. Molecular characterization and genetic diversity analysis of Jatropha curcas L. in India using RAPD and AFLP analysis. Mol Biol Rep 37: 22492257.

Vidal MC, Setiawan A, Wahyu Y. 2019. RAPD based genetic diversity, agronomic characters, and nutrition content of Timor Leste kidney bean (Phaseolus vulgaris) genotypes. Biodiversitas 20 (9): 2612 2619.

Yang XS, Su WJ, Wang LJ, Lei J, Chai SS, Liu QC. 2015. Molecular diversity and genetic structure of 380 sweet potato accessions as revealed by SSR markers. J Integrative Agric 14: 633-641.

Yulita KS, Mansur M. 2012. The occurrence of hybrid in Nepenthes hookeriana Lindl. from Central Kalimantan can be detected by RAPD and ISSR markers. Hayati J Biosci 19 (1): 18-24 